\title{
СООТНОШЕНИЕ ЛИЧНОСТИ И ОБЩЕСТВА: РАВЕНСТВО ВО ИМЯ ЦЕЛОГО
}

\begin{abstract}
Н.В. Шрамко
Современная социальная философия, ставя перед собой задачу целостного, комплексного восприятия социальной жизни и интерпретации общественных процессов, широко использует в качестве новых методологических техник особые виртуальные ситуативные модели, заимствованные зачастую из отдаленных областей науки и действительности ${ }^{1}$. Это позволяет не только выработать новые оригинальные критические теории, но возвращает современной социальной философии ее статус «общей теории общества», который был украден у нее экономическими науками, а также вызывает сегодня не только всеобщий интерес, но и утерянное было уважение заинтересованной публики. Наука, занимающаяся разработкой общей теории общества, пытаясь преодолеть «кризис предсказания» экономических теорий ${ }^{2}$, ассимилирует с разной степенью успеха этическую проблематику, с тем, чтобы объяснить не только процесс общественной и культурной модернизации, но и социальные паталогии развитых обществ. Однако основные этические концепции рассматривают в качестве базового носителя, творца и пользователя рационализирующей действительность морали исключительно индивида, современная же теория социума видит единицей общественного бытия социальное взаимодействие,

\footnotetext{
${ }^{1} \mathrm{~B}$ качестве примеров здесь можно привести использование Дж. Ролзом аппарата теории игр и концепции «общественного договора», или же понятие «нарративной связности», задействуемое Р. Дворкиным, и т. п.

2 По меткому замечанию А. Макинтайра, «Ни один экономист не предсказал экономического застоя при одновременной инфляции до их наступления» (Макинтайp A. После добродетели: Исследования теории морали. - М.: Академический проект; Екатеринбург: Деловая книга, 2000.-С. 123.).
}

Актуальні проблеми духовності 
что предполагает, как минимум, еще одного участника (актора). Тогда процесс рационализации объективной реальности эмансипируется и осуществляется в терминах справедливости и права.

Первые интеллектуальные процедуры нашего сознания непосредственно связаны с двумя способностями чувственного обнаружения действительности: распознавание подобного, а значит, равного и отличного, другого, а значит, неравного. По довольно-таки примечательному совпадению, в социальной жизни эта фундаментальная бинарность сознания может найти себе применение в поиске (который не может быть долгим) двух глобальньх форм общественного взаимодействия признания ${ }^{3}$ и господства. По мнению Гегеля, именно в борьбе за признание и господство и заключается суть механизма, запущенного Абсолютной идеей в поисках собственной свободы, создающего и воспроизводящего социум. Признание предполагает изначально равное, господство - неравное. Причем признание возможно только как взаимное обязательство, как расчет, ожидание, как добровольное принятие другого в обмен на принятие другим. Однако следует отметить, что в исторической ретроспективе «признание», как первый вариант социального взаимодействия, предполагает универсальные, коллективные качества человека, обладание которыми обеспечивает вхождение человека в целое, где каждый «имеет право» и принадлежит целому только потому, что в границах этого целого он обладает неким свойством, которое, в свою очередь, репрезентируется квантором общности. Такое качество может быть ритуально условным, искусственно конструируемым, как в древнем или феодальном обществе. Стремление к утверждению уникальности, реализуемому как неповторимость, оригинальность, своеобразие образа жизни, нарушает уравнение, где с одной стороны тождества находится индивид, а с другой - «все». Оно распознается обществом не как попытка самореализации, а как нарушение целого, а следовательно, равенства. Уникальность человеческих качеств, которые мы сегодня относим к общечеловеческим константам, в традиционных обществах не являются аргументом для распознавания справедливости. Таким образом, свобода реализуется не как свобода воли, а как совокупность некоторых прав, предоставляемых индивиду за обладание определенным качеством, необходимым для сохранения «целого». Равенство же в признании прав является критерием справедливости. Следует уточнить, что в традиционных,

\footnotetext{
${ }^{3}$ См., напр.: Фурс B.Н. Борьба за признание и моральное развитие общества в концепции Акселя Хоннета // Вопросы философии. - 2005. - № 1. - С. 159-171.
} 
доиндустриальных обществах равенство в правах, возможное только при наличии универсального качества, не означает равенства в содержании и объеме прав (равенство перед законом). Кант в «Лекциях по этике» подчеркивает: «Каждый человек обязан отстаивать свое право и следить, чтобы другие не топтали его ногами. Он не должен отказываться от человеческого преимущества «иметь право», а обязан так долго отстаивать его, как может, потому что отказываясь от своего права, он отказывается и от права называться человеком» ${ }^{4}$. И далее: «Допустим, мы работали для кого-либо, а у него отсутствует желание заплатить за это и он делает столько оговорок, что это уже задевает наше право и мы не должны позволять, чтобы с ним играли. Здесь речь идет не о жалких двух таллерах, а о нашем праве, которое представляет собой нечто большее, чем сто или тысяча талеров ${ }^{5}$. Несмотря на последнее замечание, следует отметить, что Кант не уточняет перечень «прав человека», вероятно здесь речь идет о праве любого рода, которое может быть делегировано субъекту целым в качестве свидетельства о причастности к последнему.

В эпоху Ренессанса происходит кардинальный переворот в понимании человека, который становится все более самостоятельным и независимым по отношению к сакрально патриархальному «целому», взаиморасчет по признанию прав постепенно переходит в область межиндивидуальных связей. Равенство в добродетели эпохи античности и равенство в грехе Средневековья сменяются равенством сословного достоинства эпохи Возрождения, а затем, перерастая рамки цеховой зависимости, порождает особую систему общественных связей, приближающих человека, в конечном счете, к трансцендентому «целому» настолько близко, что оно, как отмечал В. Соловьев, уже не имеет никаких общественных прав на единичного человека, если степень подчинения лица обществу не соответствует степени подчинения самого общества нравственному добру ${ }^{6}$.

Однако, чтобы «бунтующий» человек состоялся, необходимо время. Новое время. Впрочем, М. Фуко в книге «Слова и вещи» ${ }^{7}$ отодвигает поиски индивидуальности еще дальше - в XIX век. Действительно, человек, впервые отбросив абстрактный ренессансно-романтический аристократизм в понимании человеческого бытия, становится граж-

\footnotetext{
${ }^{4}$ Кант И. Лекции по этике. - М.: Республика, 2005. - С. 193.

${ }^{5}$ Там же.- С. 194.

${ }^{6}$ Соловъев B.C. Оправдание добра. Нравственная философия // Соч. в 2 т.Т. I - М.: Мысль, 1988. - С. 341.

${ }^{7}$ Фуко М. Слова и вещи. Археология гуманитарных наук-M., Прогресс, 1977.
} 
данином, полноправным участником общественного договора только в эпоху становления капиталистических отношений, когда он, осознав свое новое качество как свойство, которым обладают все в равной степени (равным по объему и содержанию), а значит, свойство, которое на новом для человека уровне позволяет через соотнесение с другими идентифицировать себя не с субъектом даваемых прав, а с личностью, которой такие права принадлежат в силу природной необходимости. Эти права конкретизируются, уточняются и в результате, человек переосмысливает и природу «целого», ассоциируемого уже с новым «Божественным абсолютом»-государством. Это уже конкретное целое, которое в свою очередь рефлектирует над обязательствами гражданина и отказывается от прав на его жизнь и свободу. Так, французская «Декларация прав человека и гражданина» 1789 года в качестве «естественных и неотчуждаемых прав» объявляет «свободу, собственность, безопасность и сопротивление угнетению» ${ }^{8}$.

Другими словами, история становления личности напрямую связана со становлением капиталистических отношений. Параллельно государству в недрах нового экономического строя возникает гражданское общество, которое вначале отождествляется с первым, затем постепенно становится самостоятельным понятием, описывающим, впрочем, поначалу нечто виртуальное. «Поскольку общества в своих отношениях сохраняют природную независимость, а индивиды подчинены и законам и людям, то возникает вопрос, не страдают ли последние от этой двойной подчиненности; и не лучше ли было бы для человека, если бы на свете не существовало никакого гражданского общества» ${ }^{9}$. Новая эпоха позволяет соотнести пользу обществу с пользой себе, называя такое совпадение высшей моралью (Бомарше, «Севильский цирюльник») и провозгласить: «Мое дело-дело всех граждан». Если в доиндустриальном обществе свобода определялась набором прав, то теперь свобода сама становится правом, а «успех рассматривается как правило справедливости» ${ }^{10}$. Равенство, которое становится гарантом новой «сделки» человека с обществом, условием принятия индивидом общественных обязательств (в том числе, и моральных), в эпоху модерна приобретает новый колорит. В этой связи можно вспомнить состоявшийся в период буржуазной революции (в 1647 г.) в Англии спор

\footnotetext{
${ }^{8}$ Современные зарубежные конституции. Сборник документов по конституционному праву зарубежных стран / Отв. ред. Б.А. Страшун. - М., 1996. - С.98.

${ }^{9}$ Руссо Ж.-Ж. Эмиль, или О воспитании.-Избр.соч.-Т.1.-М., 1961.C. 692 .

${ }^{10}$ Робеспвер М. Избр. произв. - Т. 3.- М., 1965.-С. 133.
} 
между «грандами» и «левеллерами», в котором речь шла о том, что именно должно служить основанием для взаимного признания, образуя общую идентичность членов человеческого сообщества, не «отменяя» их специфические отличия, а, напротив, интегрируя их в целое ${ }^{11}$.

Поскольку стержневой формой политической организации современного общества является система «нация-государство», то гражданское единство народа, проживающего на данной территории, определяется равенством политических прав граждан, но не этносов. Однако с начала XIX века мы знаем историю этносов как политическую историю. Возникновение национальных государств способствовало укреплению межклассового сотрудничества, а значит и унификации коллективных качеств и добавлению к их числу нового общего свойства национальности и, как следствие, появлению национализма. Освоение уравнивающей идентичности происходит чрезвычайно эффективно и агрессивно не только индивидом, но и ожившим Левиафаном. «Эгоизм, корысть, самомнение, гордость, воля к могуществу, ненависть к другим, насилие - все делается добродетелью, когда переносится с личности на национальное целое. Для нации все дозволено, во имя ее можно совершать преступления... ${ }^{12}$. Национальная мегаломания оказалась инфекционной заразой, котораяв XX в. привела к катастрофическим последствиям в виде двух мировых войн, и от которой некоторые нации не избавились до сих пор.

Эпоха модерна предлагает нам новые условия соглашения индивида и общества. Либерализм, как идеология современного общества, гарантирует всем участникам экономических отношений принятие прав отдельного человека в виде первичной субстанции и признание их более значимыми, чем коллективные, а значит упраздняет равенство через коллективные качества: наше равенство уже не зависит от гражданства, национальной, религиозной или сословной принадлежности, равенство не является свойством, которое соотносится с трансцендентальным, интерсубъективным или другого рода целым, оно исчисляется величиной единицы человеческого рода. Такое равенство является равенством человека по отношению к другому человеку: совокупность прав, предоставляемых правовым сообществом индивиду предполагает обладание всем спектром особенностей, отличающих нас от другого, а такое социальное целое репрезентируется уже как «гражданское

\footnotetext{
${ }^{11} \mathrm{C}$ м.: Капустин Б. Законодательство истины, или Заметки о характерных чертах отечественного дискурса о нации и национализме // Логос. - 2007. - № 1. C. 122 .

${ }^{12}$ Бердлев Н. О рабстве и свободе человека.- М.: АСТ, 2006.-С. 192.
} 
общество», неотделимое от конкретного индивида и порожденное его солидарностью.

Однако общество эпохи модерна, достигнув разительных успехов в экономике и выработав особые способы «коммутативной справедливости», параллельно наращивает процессы, превращающие мир в атомарный социум, уже не в виртуальном смысле Локка или Гоббса, а в режиме on line, что заставляет нас столкнуться с проблемой единства целого по-новому.

520 лет назад, в Риме, Д. Пико делла Мирандола в своей знаменитой «Речи о достоинстве человека» ${ }^{13}$ дал лучшее, на наш взгляд, определение того, что в философии обозначается термином «свобода». Он предложил человеку от лица Бога стать тем самым «свободным и славным мастером», способным сформировать себя в образе, который он сам предпочтет. Вероятно, это и должно стать тем новым качеством, которое человек обнаружит как подобное и равное в другом и которое возможно создаст новый тип «целого».

Таким образом, историю взаимного симбиоза индивида и общества можно представить как процесс развития форм признания человека и изменений форм и роли социального целого.

\footnotetext{
${ }^{13}$ Пико делла Мирандола Дж. Речь о достоинстве человека // Эстетика Ренессанса. - Т. 1.-М., 1981.
} 